\title{
LETTER
}

\section{Non-invasive ventilation for critically ill patients with pandemic H1N1 2009 influenza A virus infection}

\author{
Silvio A Ñamendys-Silva ${ }^{*}$, Marisol Hernández-Garay² and Eduardo Rivero-Sigarroa ${ }^{3}$ \\ See related research by Rello et al., http://ccforum.com/content/13/5/R148
}

We read with interest the study reported by Rello and colleagues [1]. The authors described the first 32 documented patients with pandemic influenza A H1N1 (PIAH1N1) virus infection hospitalized in an intensive care unit (ICU) in Spain. Twenty-four patients (75.0\%) had refractory hypoxemia and required advanced mechanical ventilation. Eight patients (33.3\%) received noninvasive mechanical ventilation at ICU admission. Six of these patients (75\%) required further orotracheal intubation and invasive mechanical ventilation and two (33\%) died.

Non-invasive ventilation (NIV) is not recommended for patients with PIAH1N1 virus infection complicated by pneumonia, acute lung injury (ALI) or acute respiratory distress syndrome (ARDS) because although NIV temporarily improves oxygenation and reduces the work of breathing in these patients, it does not necessarily change the natural disease course. On the other hand, NIV may increase the risk of respiratory pathogen transmission [2] and there is not enough evidence to support the treatment of ALI/ARDS with NIV. To date, three studies have suggested that NIV has not been successful in critically ill patients with hypoxemic respiratory failure attributable to PIAH1N1 virus infection $[1,3,4]$. In these studies a total of 76 patients received NIV, but $64(84.2 \%)$ of these patients required subsequent intubation and invasive ventilation.

Considering the high failure rate of NIV therapy in patients with PIAH1N1 virus infection and ALI/ARDS, the treatment of ARDS associated with the PIAH1N1 virus infection should be based upon published, evidence-based guidelines for sepsis-associated ARDS. Standard lung-protective ventilation strategies are appropriate initially $[2,5]$.

\section{Authors' response}

Alejandro Rodríguez, Ignacio Martin-Loeches, Jordi Rello; and the H1N1 SEMICYUC Working Group

We appreciate the interest of Dr Namendys-Silva and colleagues in our article [1] and their insightful observations regarding ventilator management of severe PIAH1N1 virus infection. We agree that NIV is not recommended for patients with respiratory failure due to PIAH1N1 virus infection. However, several points should be clarified. Use of NIV in ARDS remains controversial and the etiology of hypoxemia seems to be an important determinant of successful outcome. Our results describe our national clinical practice in the current pandemic and it is consistent with other reports [3,6]. Other authors have

\footnotetext{
*Correspondence: tony75ni@msn.com, snamendys@incan.edu.mx 'Department of Critical Care Medicine, Instituto Nacional de Cancerología and Instituto Nacional de Ciencias Médicas y Nutrición Salvador Zubirán, Mexico City, Mexico

Full list of author information is available at the end of the article
}

recently reported that, in centers with expertise on NIV, $30 \%$ of patients with ARDS were treated with NIV as a first-line intervention and 30 to $50 \%$ of these avoided orotracheal intubation $[1,3,6]$. Thus, only a small number of patients with ARDS benefited from NIV in expert centers, always needing close monitoring in the ICU setting. In selected patients with milder presentation a conservative ventilator approach should be considered until additional data from 2009 PIAH1N1 is obtained.

\section{Abbreviations}

ALI, acute lung injury; ARDS, acute respiratory distress syndrome; ICU, intensive care unit; NIV, non-invasive ventilation; PIAH1N1, pandemic influenza A H1N1.

\section{Author details}

'Department of Critical Care Medicine, Instituto Nacional de Cancerología and Instituto Nacional de Ciencias Médicas y Nutrición Salvador Zubirán, Mexico City, Mexico. ${ }^{2}$ Department of Anesthesiology, American British Cowdray Medical Center, Mexico City, Mexico. ${ }^{3}$ Department of Critical Care Medicine, Instituto Nacional de Ciencias Médicas y Nutrición Salvador Zubirán, Mexico City, Mexico. 


\section{Competing interests}

The authors declare that they have no competing interests.

\section{Published: 17 March 2010}

\section{References}

1. Rello J, Rodríguez A, Ibañez P, Socias L, Cebrian J, Marques A, Guerrero J, Ruiz-Santana S, Marquez E, Del Nogal-Saez F, Alvarez-Lerma F, Martínez S, Ferrer M, Avellanas M, Granada R, Maraví-Poma E, Albert P, Sierra R, Vidaur L, Ortiz P, Prieto Del Portillo I, Galván B, León-Gil C; the H1N1 SEMICYUC Working Group: Intensive care adults patients with severe respiratory failure caused by influenza A (H1N1)v in Spain. Crit Care 2009, 13:R148.

2. Hui DS, Lee N, Chan PK: Clinical management of pandemic (H1N1) infection. Chest doi:10.1378/chest.09-2344

3. Kumar A, Zarychanski R, Pinto R, Cook DJ, Marshall J, Lacroix J, Stelfox T, Bagshaw S, Choong K, Lamontagne F, Turgeon AF, Lapinsky S, Ahern SP, Smith $O$, Siddiqui F, Jouvet P, Khwaja K, Mclntyre L, Menon K, Hutchison J, Hornstein D, Joffe A, Lauzier F, Singh J, Karachi T, Wiebe K, Olafson K, Ramsey C, Sharma S, Dodek P, et al.; for the Canadian Critical Care Trials Group H1N1 Collaborative: Critically ill patients with 2009 influenza A (H1N1) infection in Canada. JAMA 2009, 302:1872-1879
4. Miller RR 3rd, Markewitz BA, Rolfs RT, Brown SM, Dascomb KK, Grissom CK, Friedrichs MD, Mayer J, Hirshberg EL, Conklin J, Paine R 3rd, Dean NC: Clinical findings and demographic factors associated with intensive care unit admission in Utah due to 2009 novel influenza A (H1N1) infection. Chest 2009 doi: 10.1378/chest.09-2517.

5. World Health Organization: Clinical management of human infection with pandemic (H1N1) 2009: revised guidance [http://www.who.int/csr/resources/ publications/swineflu/clinical_management_h1n1.pdf_

6. Antonelli M, Conti G, Esquinas A, Montini L, Maggiore SM, Bello G, Rocco M, Maviglia R, Pennisi MA, Gonzalez-Diaz G, Meduri GU: A multiple-center survey on the use in clinical practice of onoinvasive ventilation as a firstline intervention for caute respiratory distress síndrome. Crit Care Med 2007, 35:18-25.

doi:10.1186/cc8883

Cite this article as: Ñamendys-Silva SA, et al:: Non-invasive ventilation for critically ill patients with pandemic H1N1 2009 influenza A virus infection. Critical Care 2010, 14:407. 